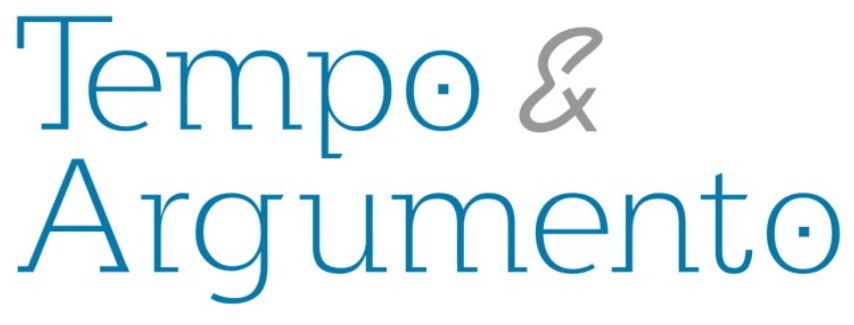

\title{
Artifícios e artefatos entre memória e história ${ }^{1}$
}

\begin{abstract}
Resumo
Este artigo pretende discutir ideias, ações e experiências de pessoas identificadas como "de esquerda" por elas mesmas e também por seus oponentes, ou mais precisamente como "nova esquerda", como proposto por vários estudiosos, para distingui-las dos grupos comunistas de formação tradicional já atuantes nas décadas precedentes, que tiveram destaque na resistência à ditadura civilmilitar que governou o Brasil entre 1964 e 1985, em particular apoiando lutas por melhores condições de vida e de trabalho, bem como por liberdades em geral, aproveitando para isto documentos produzidos por elas encontrados em fundos públicos ou privados. Em especial, o texto focaliza a participação destas esquerdas em sindicatos e movimentos sociais, e em organizações da sociedade civil e mesmo em instâncias institucionais, sempre em disputa com as oposições liberais e populistas, com o objetivo de entender a relevância ou não desta participação e, sobretudo, as possíveis influências que exerceram nos rumos assumidos pelo Brasil contemporâneo, uma vez que muitos de seus membros estavam sintonizados com as críticas da falta de independência das mobilizações e organizações das classes subalternas, com a importância da luta das mulheres e das minorias sociais por direitos, o que pode ter emprestado características peculiares ao processo de democratização do País.
\end{abstract}

Palavras-chave: Memória; História; Ditadura; Esquerdas;

Democratização.

\section{Luiz Felipe Falcão}

Doutor em História Social pela Universidade de São Paulo - USP. Professor do Programa de Pós-Graduação em História da Universidade do Estado de Santa Catarina - UDESC. Brasil luiz.felipe@mailcity.com

\section{Para citar este artigo:}

FALCÃO, Luiz Feipe. Artifícios e Artefatos entre Memória e História. Revista Tempo e Argumento, Florianópolis, v. 7, n. 16, p. 56 - 80. set./dez. 2015.

DOI: $10.5965 / 2175180307162015056$

http://dx.doi.org/10.5965/2175180307162015056

\footnotetext{
${ }^{1}$ A pesquisa para a elaboração deste artigo contou com apoio do CNPq e da FAPESC.
} 


\title{
Artifices and artifacts between memory and History
}

\begin{abstract}
This paper intents to discuss ideas, actions and experiences of people identified as "left" by themselves and also by their opponents, or as "new left" like proposed by some scholars to distinguish then of traditional formation communists groups (stalinists, trotskists, etc.) already operating since the 1950 s or before, which have been highghted in the resistence to the military-civil dictatorship that ruled in Brazil between 1964-1985, in particular supporting strugles for better conditions of life and work, as well as for freedoms in general, leveraging for this documents produced by them which are found in personal or public funds. In particular, the text focuses on the joint lefts participation in trade unions and social movements and in civil society organizations and same in institutional instances, always disputing with liberal and populist opposition, aiming to understand the relevance or otherwise of this participation and, in special, the possible influences that al of this have taken in contemporary Brazil, once many of its members was tuned with criticism of lack independence of the subordinate classes mobilizations and organizations and with the importance of women and social minorities fights for rights, what could have given such unique characteristics to the country democratization process.
\end{abstract}

Keywords: Memory; Historiy; Dictatorship; Lefts; Democratization. 
Se eu havia me engajado nesse trabalho, é porque me recusava a permitir que as pessoas $e$ as coisas desaparecessem sem deixar vestígio. Podemos algum dia nos resignar $a$ isso?... (Patrick Modiano, Primavera de cão)

Constou entre alguns eruditos que se dedicaram ao estudo da Antiguidade Clássica grega (WEINRICH, 2001; YATES, 2007) que os helenos acreditavam ter sido Simônides de Ceos o protagonista de uma situação exemplar e definidora para a secularização da poesia: convidado para louvar em versos as façanhas de um nobre da Tessália (para Weinrich, um pugilista), de nome Scopas, em meio a um banquete oferecido por este, Simônides dedicou uma parte de sua récita a louvar os heróis gêmeos Castor e Pólux, em razão do que o anfitrião se recusou a lhe pagar a íntegra do combinado pelo panegírico alegando que ele deveria se dirigir aos irmãos para cobrar deles a diferença. Em meio à zombaria dos presentes que se seguiu às palavras petulantes de Scopas, Simônides foi chamado por dois jovens fora do salão, não os encontrando, porém, e neste instante o recinto em que acontecia o festim desabou, atingindo os convivas com pedras e escombros de tal modo que eles ficaram irreconhecíveis para os parentes que ali acorreram a fim de realizar os funerais. Valendose de sua memória prodigiosa e bem treinada, contudo, o poeta recordou perfeitamente os lugares ocupados por cada um dos convivas à mesa e, assim, eles puderam ser identificados e as cerimônias mortuárias efetuadas conforme estabeleciam as tradições.

A narrativa sugeria que Castor e Pólux teriam salvado a vida de Simônides em agradecimento pelas homenagens recebidas, mas, para os seus contemporâneos, ela trazia consigo outras tantas referências importantes que convém ressaltar. Primeiro, a poesia não era mais a repetição com fervor de um ensinamento sagrado e sim um ato de criação humano favorecido pela maior ou menor engenhosidade do seu autor que, agora, passava a receber um pagamento por sua atividade, adquirindo autonomia perante os poderosos dos quais dependera até então. Segundo, o poeta constituía-se como a testemunha ocular de um acontecimento qualquer (ou como aquele que mantivera um contato direto ou indireto com uma testemunha ocular de um acontecimento qualquer) e, graças a isto, e decerto mais do que isto, como alguém capaz de recordar algo, de 
para o usufruto dos ensinamentos necessários, acomodando, desta forma, presente, passado e futuro com sua fala composta com maestria. O poema, nestas condições, surgia como um artifício e um artefato vinculado de modo indissolúvel com a memória que, terceiro, não se confundindo com o ocorrido, mantinha com ele uma cumplicidade a um só tempo irredutível e opaca.

Estas considerações um tanto ou quanto genéricas sobre poesia, memória e oralidade são úteis para indicar os nexos apertados que vinculam criação humana, capacidade de recordar e potencial de expressar. Estes fatores, aliás, não podem existir isoladamente, sem os demais, e se configuram igualmente como indispensáveis para outro gênero de composição, qual seja a produção historiográfica, com toda a sua pretensão de gerar por intermédio de hábeis artifícios, no presente, um artefato que estabeleça relações de verossimilhança com o passado e que os projete, passado e presente, na direção de futuros possíveis. Um artefato do presente, enfim, com linhagens que o vinculam com um passado do qual não é resultado imediato e automático, e com descendências que o ligam a um futuro incerto e imprevisível.

Criação humana, capacidade de recordar e potencial de expressar correspondem, inquestionavelmente, a ângulos fundamentais do ofício historiográfico, ou de certa compreensão do trabalho historiográfico, para quem a História não se confunde com procedimentos e ensinamentos a serem seguidos e prescritos, nem com neutralidade e indiferença (FEBVRE, 1985). Bem mais que isso, pode a História interferir nas tensões e conflitos que sulcam e dividem o tecido social, os posicionado numa dimensão temporal e informando as linhagens genealógicas a que estão vinculados. Nesta perspectiva, trata-se de abordar episódios, manifestações e visões de mundo da História recente da América Latina em geral, e do Brasil em particular, que ainda despertam adesões e resistências apaixonadas, as quais muito embora não possam governar estritamente o fazer historiográfico, dele não conseguem ficar de todo ausentes, caso não se queira correr o risco de esquecer, conforme alertou Benjamin, "que também os mortos não estão em 
Ilustrativa a este respeito é a análise da presença das estruturas clandestinas e semiclandestinas de esquerda no processo de rearticulação e reorganização das lutas operárias, estudantis e populares contra a ditadura brasileira implantada com o golpe de 1964, e, por conseguinte, na própria democratização que se the seguiu, o que segue provocando embates intensos em torno da construção da memória e da história contemporânea do país. Mais exatamente, ainda gera muita controvérsia o caráter do regime e do seu surgimento (ditadura ou "ditabranda", ditadura militar ou ditadura civilmilitar, golpe ou revolução), o alcance de sua intervenção na modernização econômica e na projeção internacional do país (atraindo capitais para investimento ou empréstimo voltados para ampliação da infraestrutura, concretizando um mercado interno de consumo de bens duráveis, perseguindo um lugar de preeminência para o Brasil no cenário internacional) e, por fim, mas não menos importante, a dimensão do papel das esquerdas no enfrentamento e superação do regime ditatorial em seguida à derrota das experiências de confronto armado com o regime mediante guerrilhas urbanas e rurais ${ }^{2}$. Afinal, o fim do regime foi acompanhado por um ascenso das lutas dos trabalhadores em todos os níveis, inclusive com a criação de novas estruturas de organização política (o Partido dos Trabalhadores, PT, em 1980) e sindical (a Central Única dos Trabalhadores, CUT, em 1983), que contaram com o apoio e a presença de organismos, militantes e ativistas de esquerda, ocupando posições dirigentes e disputando a hegemonia da sua condução.

Em termos de mobilização operária e de assalariados, afora lutas isoladas nos bairros e em diversas empresas por razões muito específicas como pontuais melhorias de salário e das condições de trabalho num ambiente pautado por acentuado arrocho salarial, proibição do direito de greve, rígido controle dos sindicatos e repressão generalizada contra qualquer tentativa de movimentação, a situação de descenso criada pelo golpe e, em especial, pelo seu recrudescimento a partir de 1968 só começou a ser

\footnotetext{
${ }^{2}$ Uma boa reflexão sobre "o significado e as raízes sociais da luta dos grupos de esquerda, especialmente dos armados, entre 1964 e 1974", como o próprio autor sintetizou, pode ser encontrada em Marcelo Ridenti (2010).
} 
Diretório Central dos Estudantes da Universidade de São Paulo, DCE-USP, com o nome de Alexandre Vannucchi Leme, um estudante que cursava Geologia quando foi preso e assassinado sob tortura pelos órgãos repressivos em 1973. E também é certo que estruturas semiclandestinas de esquerda como as oposições sindicais tentavam levar adiante um trabalho de base nas empresas, ao passo que militantes e ativistas aproveitavam as oportunidades abertas pelos setores progressistas da Igreja Católica, orientados pela Teologia da Libertação ${ }^{3}$, para realizar cursos e dinamizar a vida sociocultural nos bairros populares. Todavia, será necessário esperar um pouco mais para o surgimento de manifestações massivas dos trabalhadores nos lugares de trabalho e moradia, nos sindicatos e mesmo em ambientes públicos.

A motivação para o reaparecimento de mobilizações mais unificadas contou com um incentivo inesperado: estando os salários submetidos a uma correção anual em percentual definido pelo governo, o Banco Mundial, no primeiro semestre de 1977, publicou num relatório que o índice de reajuste não acompanhara a inflação em 1973, o que foi admitido também por alguns ministros do então presidente General Ernesto Geisel. Em vista de tal reconhecimento, o Departamento Intersindical de Estatística e Estudos Socioeconômicos, DIEESE, órgão de assessoramento do movimento sindical, calculou em 34,1\% a diferença não paga, diante do que várias categorias profissionais começaram a se articular para exigir o pagamento dos valores subtraídos.

Em São Bernardo, a fim de organizar a luta pela reposição, a diretoria do sindicato, presidida por Luiz Inácio da Silva, Lula, criou, numa primeira assembleia, uma Comissão de Mobilização integrada também por militantes e ativistas de esquerda, Comissão esta que

\footnotetext{
${ }^{3} \mathrm{O}$ engajamento dos setores progressistas da Igreja Católica nas lutas sociais, sobretudo nas décadas de 1970 e 1980 e em todas as regiões do país, foi decisivo no enfrentamento da ditadura brasileira, com a abertura das paróquias para os movimentos sociais, a organização das classes populares para a luta por suas reivindicações, a elaboração de material de divulgação, textos proféticos e de denúncias, etc. Do ponto de vista intelectual, um de seus pontos altos foi a publicação, em 1975, de uma obra reunindo estudos de pesquisadores renomados do Centro Brasileiro de Análise e Planejamento, CEBRAP, como Fernando Henrique Cardoso e Lúcio Kowarick: São Paulo 1975: crescimento e pobreza, a pedido da Pontifícia Comissão de Justiça e Paz da Arquidiocese de São Paulo.
} 
para a possibilidade de uma greve. Seja como for, a convocação obteve ampla repercussão e uma assembleia com cerca de 3 a 5 mil operários, a maior em todo o país desde 1968, debateu os rumos a seguir para recuperar os valores sonegados, associando a isto outros temas sensíveis para aquele momento como liberdade e autonomia sindical, livre negociação com as entidades patronais e direito de greve.

Repercutindo a novidade, a revista semanal Veja, sintonizada com as parcelas das classes dirigentes que começavam a se afastar da ditadura por divergir de seu “intervencionismo econômico excessivo" e "nacionalismo retrógado", além de seu antiliberalismo político que dificultava a "redemocratização do país", divulgou na sua edição de 14 de setembro de 1977, com a chamada de capa "Redemocratização: e os operários?", uma ampla matéria sobre o assunto intitulada “A questão operária" que iniciava do seguinte modo:

Pela primeira vez neste governo, o salão de reuniões do $5^{\circ}$ andar do Ministério da Fazenda, em Brasília, abriu suas portas para uma delegação de líderes sindicais operários. E esta não seria a única vitória conquistada na semana passada pelos metalúrgicos de São Paulo, que foram discutir com os ministros da área econômica e trabalhista uma ampla pauta de assuntos que preocupam a categoria. Além disso, o encontro serviu para oficializar definitivamente a inclusão da chamada "questão da classe operária" no debate sobre a redemocratização do país - ou seja, de que maneira não apenas engajar os assalariados nesse debate mas em especial considerar sua legítima e livre representatividade em uma nova ordem liberal. (VEJA, 14 de setembro de 1977, 20)

A matéria continha várias entrevistas com integrantes do governo, lideranças empresariais e dirigentes de sindicatos de trabalhadores, com declarações como as do Delegado Regional do Trabalho em Pernambuco, Romildo Alves Leite, para quem os sindicatos são formados "de homens rudes, despreparados", "que gastam seu dinheiro fechando lupanares"; do presidente do Sindicato da Indústria da Construção Civil de Belo Horizonte, Maurício Roscoe, que muito embora tenha se declarado a favor de "um governo aberto, da democracia", complementou que isto só poderia acontecer "com 
qual "acabou a briga entre patrão e operário", pois o governo "faz tudo para nos ajudar, dá tudo o que pedimos", arrematando: "Não falo de política, o trabalhador não está preocupado com isso."

Este conjunto de referências, no corpo de uma reportagem jornalística, faz as vezes de artifícios que, com engenhosidade ou artimanha, são mobilizados para tecer um artefato capaz de exprimir a opinião editorial do órgão que o veicula e, ao mesmo tempo, de buscar um convencimento (e um consentimento) dos leitores para as ideias que difunde. Mesmo quando as declarações de alguns dirigentes sindicais expõem reticências ou até servilismo perante as autoridades governamentais, isto apenas evidencia a sagacidade da composição no sentido de defender a necessidade de "engajar os assalariados (...) em uma nova ordem liberal”. Em função disto, o artifício não contradiz o artefato, isto é, não embaça a perspectiva da revista, que percebe com nitidez a mudança em curso com aquelas primeiras mobilizações de trabalhadores em muitos anos, o que a leva a uma conclusão peremptória:

Quanto à qualidade da abertura que se pretende dar aos trabalhadores, a discussão em torno do reajuste compensatório - um prato inegavelmente indigesto para todos - surge plena de ensinamentos. Se, em 1973, ao ocorrerem os erros no cálculo da inflação, tivessem os organismos sindicais suficiente desembaraço no debate de suas reivindicações, o mal teria sido cortado no nascedouro. $O$ erro seria denunciado e o problema resolvido em tempo hábil para ambas as partes.

O governo, contudo, recusou qualquer revisão sob a alegação de que os valores já haviam sido compensados, e as empresas não aceitaram negociar nada, inviabilizando aquela mobilização inicial, mas produzindo um descontentamento profundo e generalizado entre os trabalhadores. O resultado desta combinação entre sentimento de injustiça, frustração e contrariedade não se fez por esperar e, em maio do ano seguinte, 1978, depois de rápidas paralisações parciais em algumas fábricas, os operários da montadora Scania entraram em greve, paralisando a fábrica por sua própria conta e sem 

semelhantes em outros municípios do Estado de São Paulo, ensaiando desta maneira os primeiros passos do que ficaria conhecido como "novo sindicalismo brasileiro", ou seja, uma confluência entre revolta pelos baixos salários e péssimas condições de trabalho, compromisso com a organização de base a partir das empresas e aspiração a uma plena autonomia e liberdade sindical. ${ }^{4} \mathrm{E}$, nos anos seguintes, 1979 e 1980, duas grandes greves gerais mobilizaram a categoria, agora sob a direção efetiva do sindicato, rompendo na prática a legislação que coibia o direito de greve e instituindo um paradigma de rebeldia operária que seria seguido pelo país afora ao longo da década de 1980.

$\mathrm{Na}$ área de abrangência do Sindicato dos Trabalhadores nas Indústrias Metalúrgicas, Mecânicas e de Material Elétrico de São Bernardo do Campo e Diadema (doravante Sindicato dos Metalúrgicos de São Bernardo e Diadema), as mobilizações reverberam em certa medida uma sequência de ações desencadeadas pela entidade, como o I, II e III Congresso dos Trabalhadores nas Indústrias Metalúrgicas de São Bernardo do Campo e Diadema, respectivamente em 1974 (setembro), 1976 (setembro) e 1978 (outubro) e o I Congresso da Mulher Metalúrgica (janeiro de 1978), evidenciando uma progressiva radicalização nas discussões e formulações. Sua principal liderança, Luiz Inácio da Silva, ingressara na direção do sindicato em 1969 como suplente do Conselho Fiscal, tendo passado a ter um cargo executivo na eleição de 1972 e assumido a presidência na eleição de 1975, igualmente numa trajetória de progressivo comprometimento com a organização nas fábricas e mobilização da categoria por melhores salários e condições de vida.

Mais ainda, esta inflexão contou com a participação significativa de militantes de organizações clandestinas e de ativistas independentes de distintas correntes das

\footnotetext{
${ }^{4}$ Cabe destacar também que, em 27 de agosto de 1978, o Movimento contra o Custo de Vida realizou na Praça da Sé, em São Paulo, uma das primeiras manifestações populares de contestação à ditadura depois de 1968: organizado por donas-de-casa em sua maioria das periferias pobres e apoiado pela Igreja Católica, o ato foi reprimido com bombas e cães pela Polícia Militar, obrigando os participantes a se refugiarem na catedral. O movimento havia recolhido 1,3 milhão de assinaturas contra a carestia, mas elas foram tidas como falsas pelo presidente Geisel.
} 
organizou para desenvolver cursos profissionais e da Educação Básica (primeiro madureza, depois supletivo), em que muitos professores integravam ou haviam integrado estruturas clandestinas de esquerda; do Departamento de Cultura, em que nasceu o grupo de teatro Ferramenta e que promoveu um curso de cinema promovido por Renato Tapajós, antigo integrante da Ala Vermelha (uma cisão na década de 1960 do Partido Comunista do Brasil, PCdoB, de inspiração maoista naqueles idos e o primeiro organismo a fazer formalmente autocrítica da luta armada, em 1971), iniciando uma longa parceria que teria como resultado a produção de vários documentários patrocinados pelo sindicato; a fundação do $A B C D$ Jornal sob a liderança de Júlio de Grammont, também antigo militante da Ala Vermelha, periódico este que passou a representar oficiosamente a diretoria do sindicato quando este sofreu intervenção governamental durante as greves de 1979 e 1980 (PRIMO, 1997; PARANHOS, 2002; FREIRE, 2006).

Em verdade, todavia, a recepção deste "novo sindicalismo" por parte das esquerdas conjugou surpresa, encantamento e desconfiança. Surpresa porque, muito embora existissem indícios crescentes do desgaste da ditadura e de sua legislação repressiva, bem como de uma lenta retomada de movimentos massivos de protesto por melhores condições de vida e liberdades, também havia claras evidências de que o regime mantinha pronunciada capacidade de resistência, reforçada pelo receio do empresariado e das lideranças liberais face à possibilidade de movimentações das classes trabalhadoras e das camadas populares, o que tendia a estimular pactos com os setores menos intransigentes da ditadura, enquanto que, por seu turno, as lutas operárias e dos assalariados em geral confrontavam-se com as sequelas dos vários anos de desmobilização e mesmo com uma renovação geracional, que acompanhara as importantes transformações por que passara o Brasil, que limitava em muito a transmissão de experiências. Encantamento, pois greves e manifestações com dezenas

\footnotetext{
${ }^{5}$ Vale notar que, em outras bases sindicais metalúrgicas e, sobretudo, em categorias profissionais como bancários, jornalistas e professores da rede pública de ensino, estruturas clandestinas e semiclandestinas de esquerda desempenharam papéis de grande liderança.
} 
ou centenas de milhares de pessoas eram como que um sonho materializando-se em realidade, eram algo que a maior parte dos militantes e ativistas de esquerda nunca haviam presenciado e que traziam consigo novidades em relação ao que havia predominado antes do golpe de 1964, como a fragilidade da organização de base ou a acentuada centralização e verticalização das entidades sindicais.

A desconfiança de parte das esquerdas em face do "novo sindicalismo", em especial o surgido entre os metalúrgicos de São Bernardo do Campo e Diadema, decerto, envolvia diversas questões. Em primeiro lugar, trata-se de um sindicalismo que surgira no interior de uma estrutura sindical burocratizada e fortemente vinculada ao Estado, combinando de maneira singular movimentos combativos e acomodações pragmáticas na ordem vigente. ${ }^{6}$ Por exemplo, um documento do sindicato dando conta das atividades da comissão formada pela diretoria e associados em assembleia de 14 de agosto de 1977 a fim de mobilizar a categoria pelos 34,1\%, em seu item 8, pregava a criação "de grupos de fábrica de apoio, divulgação da luta e mobilização da categoria...”, mas, em seu item 10, explicitava: "Não deverá ser desprezada a viabilidade de movimento grevista, desde que amparado na lei 4.330 e que a categoria esteja preparada para tanto."7 Ou seja, reconhece explicitamente a necessidade de observar a chamada Lei de Greve imposta em 1 de junho de 1964, logo após o golpe, que praticamente impedia este tipo de movimento uma vez que exigia, para sua efetivação, um aviso prévio de 5 dias, além de proibir sua propaganda e de conferir à Justiça do Trabalho a prerrogativa de decidir sobre a

6 O desafio de compreender o "novo sindicalismo" não se limitou às estruturas clandestinas e semiclandestinas de esquerda, como o provam as polêmicas em torno de sua interpretação no ambiente acadêmico. Para Maria Hermínia Tavares de Almeida (1996), por exemplo, existia nele algo de "aristocracia operária" semelhante ao sindicalismo norte-americano (combativa, enraizada nos locais de trabalho e bem preparada para defender os interesses de seus representados) e, por isto mesmo propensa a uma certa acomodação na ordem social vigente. Já Ricardo Antunes (1995) concentra-se na elaboração de uma classificação dos movimentos grevistas, considerando as mobilizações em São Bernardo espontâneas, pois apesar de terem alcançado uma dimensão política, não teriam sido dirigidas nesta perspectiva. Contudo, existe como que um consenso no sentido de que o "novo sindicalismo" não obteve sucesso quanto a algumas de suas principais premissas, a organização autônoma nas empresas e a ruptura com a estrutura sindical oficial, seja por suas debilidades (a Oposição Sindical Metalúrgica de São Paulo, a mais destacada e influente do país, jamais teve sucesso nas disputas pela direção do sindicato, além do que o patronato conseguiu suprimir as comissões de empresa formadas no auge das mobilizações), seja por acomodamento ante benesses como o imposto sindical cobrado das empresas pelo Estado e distribuído por este aos sindicatos). Um balanço elucidativo desta discussão acadêmica pode ser lido em Naiara Dal Molin (2013).

7 Documentos diversos, Acervo 72, Organizações e Partidos Políticos, caixa 3, documentos avulsos, Arquivo Edgard Leuenroth da Universidade Estadual de Campinas (UNICAMP). 
irreversível e que ele iria retornar ao seu emprego na fábrica, só reassumindo o comando do movimento alguns dias depois.

Em segundo lugar, aquela desconfiança podia ser explicada igualmente pela própria desconfiança dos "novos sindicalistas" com certas práticas de parcelas das esquerdas, vistas por eles como aventureiras e vanguardistas por não respeitarem as condições objetivas do momento político e o estágio de amadurecimento dos trabalhadores. Exemplar quanto a isto foi a crescente tensão aparecida depois das greves de maio de 1978 entre a direção do Sindicato dos Metalúrgicos de São Bernardo e Diadema e os professores de sua escola, o CET, que publicamente e no interior da entidade criticavam, junto aos seus alunos, o desempenho da diretoria nas mobilizações, o que culmina, em 1979, com a decisão irrevogável da diretoria de fechar definitivamente a escola (PARANHOS, 2002, 129, 143 e 160). Conforme recordou um dos diretores da entidade, Devanir Ribeiro, anos depois,

Esses professores tinham uma visão mais ideológica e menos prática. Não só eles, como a Pastoral Operária, todo mundo era contra a gente. Eles não entendiam naquela época, mas depois eles entenderam, a transformação da forma capital-trabalho (...) Todo dirigente que se sentasse à mesa com o empregador estava traindo a classe trabalhadora. (...) Se o Lula aparecia na TV Globo, nossa senhora, no outro dia era pau, não podia, aquilo era burguês. (PRIMO, 1997, 102) ${ }^{8}$

\footnotetext{
${ }^{8}$ Ilustrativa das dissonâncias entre as lideranças sindicais e algumas estruturas clandestinas de esquerda foi a defesa, por parte da Organização de Combate Marxista Leninista Política Operária, OCML-PO (derivação da Organização Revolucionária Marxista Política Operária, ORM-PO, primeiro agrupamento da chamada "nova esquerda" no Brasil, fundada em 1961), em pleno 1976, ou seja, antes de qualquer possibilidade de mobilização menos dispersa e isolada da classe operária, de um índice de reposição salarial de $200 \%$ (fazendo autocrítica dos $110 \%$ propostos antes...), diante de uma inflação na faixa de $45 \%$, como garantia de luta contra o arrocho "no terreno político", pois outros índices "encaminham apenas uma luta de resistência econômica" (jornal clandestino Política Operária, n. 46, sem capa, mais provavelmente de junho ou julho de 1976, pág. 8, Acervo 72, Organizações e Partidos Políticos, caixa 2, documentos avulsos, Arquivo Edgard Leuenroth da UNICAMP). Uma contundente avaliação da PO por um de seus dirigentes históricos, Raul Villa (codinome de Eder Sader) apareceu na revista clandestina Brasil Socialista n. 7, de outubro de 1976, com o título "Para um Balanço da PO" (Arquivo Edgard Leuenroth da Universidade Estadual de Campinas, Acervo 72, Organizações e Partidos Políticos, caixa 2).
} 
Conforme se pode notar, a distinção entre os diretores do sindicato e aqueles militantes de estruturas clandestinas de esquerda que atuavam no CET (neste caso específico, integrantes do grupo trotskista Organização Socialista Internacionalista, que editava e continua editando o jornal O Trabalho), era vista pelos primeiros como um contraste entre prática, ou pragmatismo, e ideologia. E, neste último caso, também estariam incluídos outros atores, como a Pastoral Operária da Igreja Católica, numa crítica indireta à Oposição Sindical Metalúrgica de São Paulo (uma frente única sindical e política com importante inserção na categoria na segunda metade da década de 1970 - quando liderou uma ampla e extensa greve, em 1979 - e ao longo da década seguinte), na qual os operários cristãos de esquerda tinham grande influência e liderança e não escondiam suas ressalvas em face do que seriam atitudes dúbias ou conciliadoras da diretoria do Sindicato dos Metalúrgicos de São Bernardo do Campo e Diadema.

E, em terceiro lugar, tal desconfiança prendia-se também aos conceitos (e preconceitos) de uma formação marxista-leninista ortodoxa da parte daquelas esquerdas, segundo a qual elas seriam as únicas e legítimas portadoras da autêntica consciência de classe do proletariado, o que não facilitava em nada o convívio com sindicalistas que, paulatinamente, cresciam em termos políticos por meio do aprendizado nas lutas e da intervenção de ativistas de esquerda nada ortodoxos e que respeitavam bastante a autonomia das entidades e dos movimentos sociais. E, neste particular, as desconfianças só fizeram aumentar quando sindicalistas e ativistas sinalizaram a importância de fundar um partido político para representá-los e defender suas bandeiras de luta, o que viria a se constituir como o Partido dos Trabalhadores, PT, entre 1979 e 1980 (HUMPHREY, 1982, SADER, 1988).

Exemplo disto está contido em um texto datilografado encontrado num dos acervos do Arquivo Edgard Leuenroth, da UNICAMP, sem data e sem identificação, mas que pelo conteúdo não deixa margem de dúvida ter sido redigido por algum militante operário de uma estrutura clandestina atuante em São Bernardo do Campo, contendo críticas à condução da diretoria do Sindicato dos Metalúrgicos local durante a mobilização pelos 34,1\%: 
Nesse meio tempo, depois da segunda assembleia, o pessoal da diretoria do sindicato que até aí vinha assumindo todas as propostas e participando dos encaminhamentos, começou a dar para trás, não se mobilizando para a formação de grupos nas fábricas, dando uma esfriada na mobilização, o que ajudou a atrasar, a paralisar um pouco da luta. (...) (Acervo 72, Organizações e Partidos Políticos, caixa 3)

Mais contundente, um outro documento encontrado no mesmo acervo e intitulado "O chamado Partido dos Trabalhadores e os interesses da classe operária", também sem data e sem indicação de autoria, dedica-se a combater a proposta de formação do PT, afirmando que o crescimento das lutas operárias levou a burguesia a “permitir e mesmo apoiar o surgimento de lideranças sindicais mais representativas" e a “estimular a criação de novos partidos que atuem dentro dos limites permitidos pelas regras de funcionamento do parlamento burguês e que apresentem propostas mais atraentes para a classe operária", visando "evitar que os trabalhadores se organizem nos seus locais de trabalho de maneira independente (...)" (5 e 6). E, depois de chamar Lula de "líder autêntico", compara o PT com o Partido Trabalhista inglês e com os partidos socialistas de Espanha e Portugal, para defender a formação de um autêntico partido revolucionário (9 e 10) e conclui seu raciocínio do seguinte modo: "Tudo isto mostra que o PT tem muito pouco a ver com a classe operária. É impossível qualquer aliança, qualquer tentativa de conciliação e inclusive de aproveitar brechas de um PT para atuar mais à esquerda...” (10).

Este tipo de posicionamento, porém, não era uma unanimidade nas esquerdas, como demonstram os já citados exemplos do $A B C D$ Jornal ou dos documentários filmados por Renato Tapajós. Em reforço deste argumento, podem ser mencionadas as orientações formuladas pela direção nacional de uma das estruturas clandestinas de esquerda mais atuantes na época, o Movimento pela Emancipação do Proletariado, $M E P^{9}$, no seu órgão oficial, Nova Luta, em editorial de setembro de $1978^{10}$. Depois de creditar os movimentos grevistas em todo país às reverberações de uma crise econômica e política, o que potencializou o descontentamento e o desejo de mudanças, mas assinalando o caráter ainda econômico das reivindicações (ainda que tenham alcançado dimensão política por desrespeitar a lei de greve) e um tanto fragmentado das mobilizações, o texto apela para um comprometimento sempre maior dos militantes e

\footnotetext{
${ }^{9}$ Organização de esquerda surgida de uma cisão da POLOP e atuante no Brasil nos anos 1970 e 1980.

${ }^{10}$ Agradeço a Carlos Henrique Menegozzo pela indicação da existência deste rico acervo.
} 

sua atitude perante este "novo sindicalismo":

(...) Dessa "frente ampla" podemos destacar duas alas mais gerais. Uma, mais combativa, da qual participam o Lula, o Olívio, dos bancários de Porto Alegre, o presidente (sic) dos sindicatos dos metalúrgicos de Santos, Ronaldo "Petroleiro", João Paulo, de Monlevade, e outros. A outra ala seria dos pelegos tradicionais que vão, uns mais, outros menos, adotando posturas de oposição ou suas reivindicações, como é o caso de Marcílio, em Sto. André, e de Enos em Osasco. O fato concreto é que em particular a primeira ala vem desempenhando um papel mais ativo na luta contra o sindicalismo atrelado e pelego. (...) Em virtude de sua prática atual, devemos considerá-los como aliados na luta contra o sindicalismo atrelado e pelego, ainda que sejam vacilantes e contraditórios.

Isto é, diante da crise, do crescente descontentamento e do surto grevista, as direções sindicais estariam adotando duas posturas diferentes: uma, "mais combativa", encampava sem maiores restrições as bandeiras das oposições, como liberdade e autonomia sindical, direito de greve e organização pela base nas empresas, e outra, menos inclinada ao ativismo que o momento impunha, mas também incorporando aqui e ali as reivindicações das oposições e se distanciando do tradicional peleguismo acomodado e policialesco. Defrontados com este quadro, os militantes e simpatizantes não deveriam vacilar em considerar os primeiros como "aliados na luta contra o sindicalismo atrelado e pelego", mesmo reconhecendo que eles assumem em várias circunstâncias comportamentos que, de acordo com o periódico, são "vacilantes e contraditórios".

Tomando como referência este diagnóstico, o editorial complementa:

Hoje essa corrente de Lula e outros representa uma corrente de oposição. (...) enquanto essas correntes criarem condições para o prosseguimento da luta contra o peleguismo e o sindicato burocrático e atrelado, é nosso papel estar aí presentes para que o programa mínimo de oposição seja levado à prática, aproveitando ao máximo as oportunidades que se abrem em sindicatos conduzidos por essas oposições para aumentar nossa força, para aumentar nossa liderança. (...) 
Seria um erro nosso lutar para formar novas oposições nos locais onde as direções sindicais tendem a manter, ainda que com vacilações, uma atitude de oposição ao sindicalismo pelego e atrelado. (...)

Depois de um longo período de severa repressão e sem maiores movimentações massivas de protesto, não possuindo uma ampla e profunda inserção entre os trabalhadores, tendo como ponto de partida uma conjuntura que se modificava com rapidez e sem quase nenhuma conexão com experiências anteriores, é bastante perceptível a dificuldade encontrada pelos redatores do periódico em caracterizar com precisão o ambiente com que se defrontavam. Não há artifícios capazes de esculpir um artefato como o fizera a revista Veja numa ótica liberal tendo em mira a “redemocratização” do país, isto é, um parâmetro de retorno a uma ordem institucional sob hegemonia das classes econômica e politicamente dirigentes. Para as esquerdas, e para o MEP em especial, o desafio era mais complexo, uma vez que sua influência não era substantiva mesmo junto ao "novo sindicalismo", incluindo Lula, que compunha uma “corrente de oposição" contra o "sindicato burocrático e atrelado", chegando a assumir uma "atitude de oposição" com "vacilações" que são apontadas, mas não dissecadas. Em decorrência, seria de fato um "erro", ou mais propriamente um suicídio político, formar oposições sindicais em que estas direções estão à frente das entidades sindicais, cabendo ao invés disto atuar junto com elas para implementar o "programa mínimo de oposição”.

Isto fica ainda mais evidente num documento intitulado "A discussão da tática numa reunião ampliada operária (uma contribuição para a discussão)", datado de 1978 (provavelmente meados do ano) e assinado pelo Comitê Regional de São Paulo deste mesmo agrupamento. ${ }^{11}$ Aqui, aparece uma explícita preocupação em assegurar coesão política diante de tensões que parecem ter surgido com o cenário proporcionado pelos movimentos grevistas e, também, com a decisão de apoiar, nas eleições parlamentares que seriam realizadas no final deste mesmo ano, e pela primeira vez (até então o posicionamento era pelo voto nulo), “candidatos combativos" lançados na legenda do Movimento Democrático Brasileiro, MDB, o partido da oposição consentida que a

\footnotetext{
${ }^{11}$ Arquivo Edgard Leuenroth da Universidade Estadual de Campinas, Acervo 72, Organizações e Partidos Políticos, caixa 2.
} 
eles trabalhadores assalariados ou não.

Coerente com esta intenção, o texto começa com menções de apoio à organização, como "nós devemos ter amor pelo MEP" ou "foi no MEP que eu conheci o espírito partidário", acompanhados de um breve censura ao fato de que a linha política teria sido formulada "sem um processo mais democrático de discussão e decisão" (2). Em sequência, ele permite compreender o que estaria contido no documento de tática, a saber: havia uma crise da ditadura enquanto regime, agravada por uma crise na economia, que não foi provocada pelo movimento de massas mas, sobretudo, pelo fim do "milagre" (o período de crescimento econômico acelerado ${ }^{12}$ ) e pelas disputas interburguesas que então começaram a acontecer, sendo que as principais forças presentes seriam a representada pela proposta governamental de distensão gradual capitaneada pelo então presidente general Ernesto Geisel e seu mais notório assessor, general Golbery do Couto e Silva, a constituída pelos liberais da Frente Nacional de Redemocratização reunindo o general Euler Bentes Monteiro mais o MDB e setores da Aliança Renovadora Nacional, ARENA (partido oficial do governo) e, por fim, a formada pela "social-democracia", isto é, por antigos líderes populistas, novos líderes sindicais e setores do $\operatorname{MDB}(3)$.

Com base nestas análises, o documento passa então a reproduzir as falas dos operários presentes, de início para fazer uma avaliação das greves nas fábricas iniciadas em São Bernardo do Campo e que se espalharam depois para outras áreas e categorias:

No $A B C$ as greves se deram de forma espontânea ou pela presença de sindicalistas combativos dentro de algumas fábricas, como por exemplo a Scania, mas na minha área a Oposição Sindical se adiantou procurando agitar a greve e o índice de $20 \%$, tirando panfletos para cada fabrica, e com isto conseguindo várias greves. Neste sentido, muitas se deram de forma espontânea, mas naquelas em que a Oposição Sindical estava presente se conseguiu um maior grau de mobilização e organização. (4)

\footnotetext{
${ }^{12}$ Para uma boa análise do "milagre" e suas implicações em termos do consentimento popular obtido então pelo regime ditatorial, ver Cordeiro (2015).
} 
Ou ainda:

Na minha área, a gente tem discussão com alguns companheiros de outras tendências. Esses companheiros são teimosos em afirmar, diante de cada fato, que sem organização nas fábricas, sem a formação de comissões de fábrica, é impossível qualquer luta. Pois bem: esses companheiros viram algumas fábricas entrarem em greve sem ter sequer um só elemento de oposição. Tem também outros companheiros que, ao proporem trabalhar no sentido de tirar uma greve, afirmavam que a massa não estava preparada, que não havia clima e coisa e tal. Pois bem: dois dias depois a fábrica desses companheiros entrou em greve sem precisar sequer de uma intervenção da vanguarda. (...) Mas isto não é tudo, pois esses companheiros, ao desacreditarem nas condições favoráveis para as greves, abstiveram-se de intervir, de preparar e de mostrar os caminhos para a luta. (...) Mas não foi em todas as fábricas que as coisas se deram assim. Naquelas em que havia alguma preparação, ou onde havia algum nível de organização, foi possível tirar uma greve mais organizada, foi possível realizar assembleias de fábrica, com a presença do sindicato mas não com o controle dele, e com a presença do patrão. Nessas fábricas o saldo foi maior. (7 e 8)

E mais outro, aparentemente em São Bernardo do Campo ou em outro lugar que contava com uma direção sindical considerada como "de oposição":

Lá na minha área não tem oposição formada, tem pessoal de oposição que aparece nas assembleias, que faz seu trabalho. Apesar do ... ser combativo, em muitos momentos ele boicota a presença do pessoal de esquerda. (...) numa assembleia, o pessoal de oposição propôs que se tirasse um Comitê de Anistia na área, foi ganha a proposta, o ... não encaminhou, esvaziou a proposta fazendo um Comitê de Defesa dos Direitos Humanos e ainda capitalizou para si a proposta. Lá na área é mais fácil o sindicato arrastar a esquerda do que ela se aproveitar das brechas criadas. (10: o nome do dirigente sindical não consta do texto)

Adotando um procedimento que faz recordar Simônides de Ceos em sua operação memorialística para identificar os mortos no funesto banquete para o qual fora convidado, muito embora no documento em questão - elaborado possivelmente a partir de atas ou de gravação de áudio - o que importava não era fixar o lugar de pessoas, por desprezíveis que fossem, e sim palavras, reflexões e sentimentos, o autor (ou os autores) do texto mostrava uma nítida intenção de induzir a uma performance. Diante de condições objetivas favoráveis para a deflagração de greves, ainda que restritas a reivindicações econômicas por melhores salários e condições de trabalho, mas assumindo 
a organização no interior das fábricas, bem como avançar na formação de uma consciência política.

O grande dilema, porém, é que não havia consenso entre os integrantes destas direções sindicais combativas, oposições sindicais e militantes das esquerdas, quanto a muitos daqueles aspectos, fossem eles as condições objetivas favoráveis para movimentos grevistas mais amplos do patronato e da própria ditadura, ou o tipo de consciência política a formar. E, confrontados com suas próprias debilidades e com as limitações das lutas operárias naquelas circunstâncias, bem como se deparando com a liderança nelas assumida pelas direções sindicais mais combativas, restava aos militantes operários de esquerda reconhecer, no que tange àquelas direções sindicais combativas, que era "mais fácil o sindicato arrastar a esquerda do que ela se aproveitar das brechas criadas". Coerente com isto, num documento datilografado escrito por um metalúrgico militante de esquerda, sem título e sem data, ao que parece da mesma organização partidária e da mesma época, para ser distribuído a outros operários com o propósito de explicar a situação vivida e convocar para a luta, pode-se ler a certa altura:

[A diretoria do sindicato] é a mesma que toma café com os operários e mete o pau nos patrões, é a mesma que senta com a gente e nos impressiona, logo a seguir esfria a animação que às vezes ela própria criou, só porque a Justiça do Trabalho negou-se a atender as reivindicações. Como é duro e delicado trabalhar no Sindicato com este tipo de diretoria. Mesmo assim, nós insistimos...

Ficou provado que os atuais dirigentes sindicais são "moças de salão". 0 que fazem é alisar os tapetes, festinhas, assistência social, apelar e puxar o saco do governo e dos patrões... (2 e 3$)^{13}$

A tentativa de captar o que seriam as ambiguidades contidas nas condutas assumidas pela diretoria do sindicato, a princípio uma diretoria combativa, e os desapontamentos que suscitam, ficam bem evidenciados no correr das linhas: trata-se de

\footnotetext{
${ }^{13}$ Arquivo Edgard Leuenroth da Universidade Estadual de Campinas, Acervo 72, Organizações e Partidos Políticos, caixa 3.
} 
criou". Por isto, completa, tal diretoria se comporta como "moças de salão", alisando os tapetes em que pisam durante as festinhas promovidas pela entidade, no agenciamento de atividades de assistência social, nos encontros e reuniões com o governo e os patrões. Como caracterizar com precisão uma diretoria deste tipo? Como garantir que ela cresça politicamente e seja fiel àquilo que um militante de estrutura clandestina de esquerda aprendeu a considerar como os autênticos interesses da classe operária como um todo? Ou, ao contrário, como desafiar e superar a liderança que ela ostenta? De fato, para quem está ali no dia a dia, é “duro, é “delicado", é arriscado, pois pode comprometer todo o trabalho e queimar o militante, dissipando num único instante o esforço que vinha sendo realizado há tempo.

As dificuldades e contradições vão marcar, assim, a presença das esquerdas nesta reanimação das lutas dos trabalhadores por melhores salários, condições de vida e de trabalho e liberdades, no contexto de desagregação paulatina da ditadura. E, para aquelas que insistiam numa apropriação ortodoxa do leninismo, os paradoxos só farão crescer na medida em que avançava e se consolidava a construção de estruturas legais políticas e sindicais, como o PT e a CUT, como expressão do movimento dos trabalhadores. Por um lado, o aparecimento destas estruturas legais será recebido com entusiasmo por várias estruturas clandestinas e semiclandestinas de esquerda, bem como por ativistas e coletivos remanescentes destas estruturas (caso, por exemplo, dos já referidos Ala Vermelha e MEP, bem como da Ação Popular Marista Leninista, APML), uma vez que permitia romper o isolamento social, sobretudo no meio operário, que amargavam em quase todas as frentes de atuação. Mas, por outro lado, a notória heterogeneidade daquelas estruturas legais trazia consigo a obrigação de competir com forças poderosas pelo seu direcionamento e, mais que tudo, colocava sob tensão o desígnio de que era imprescindível formar o partido revolucionário, levando algumas tendências de esquerda a tratar estas novas estruturas como frentes relativamente frouxas para lhes permitir, em outros ambientes como o movimento estudantil, alianças 

Amazonas $(1981,10) .^{14}$

O movimento sinuoso que se pode observar na documentação produzida pelas esquerdas naquele período é, nestes termos, compreensível e mesmo inevitável, tornando suas opções por vezes incongruentes com os objetivos que perseguiam a curto, médio e longo prazo. E isto apenas se acentuou quando, nas eleições de 1982, as primeiras em que o PT participou, apesar das enormes expectativas e das simpatias que ele despertava, seu desempenho foi péssimo, desvelando o hiato existente entre as mobilizações dos trabalhadores e sua consciência política, atestando a impotência do partido em se apresentar como alternativa para o Brasil num contexto de crise econômica e decomposição da ditadura e precipitando uma disputa interna sobre os rumos a tomar. Como expressão disso, conforme sustentaram várias de suas lideranças em uma série de debates sobre a conjuntura e os destinos do partido, esta estrutura legal corria o duplo risco do isolamento social, caso optasse por um caminho de doutrinarismo programático, e de cooptação para o interior da ordem social vigente, caso escolhesse se acomodar dentro das instituições vigentes, em especial nos parlamentos. ${ }^{15}$

Em suma, estruturas legais como o PT e a CUT correspondiam a articulações inéditas no país, reunindo lideranças sindicais de grande prestígio entre os trabalhadores e os movimentos populares, parcelas das igrejas progressistas (notadamente dos setores da Igreja Católica influenciados pela Teologia da Libertação), intelectuais, estudantes, artistas e profissionais liberais, alguns dos quais eram ativistas ou militantes organizados

${ }^{14}$ Que o PCdoB não estava sozinho neste julgamento pode ser comprovado pelo documento intitulado "O “Partido dos Trabalhadores' e os interesses da classe operária" (Arquivo Edgard Leuenroth da Universidade Estadual de Campinas, Acervo 72, Organizações e Partidos Políticos, caixa 2), sem assinatura e sem data, mas provavelmente de um grupo trotskista em 1980, onde se lê: “... o PT tem muito pouco a ver com a classe operária. É impossível qualquer aliança, qualquer tentativa de conciliação e inclusive de 'aproveitar brechas de um PT para atuar mais à esquerda', como já foram por demais usadas para justificar a atuação no e para o MDB, contribuindo somente para atrelar a classe operária à burguesia." (10)

${ }^{15}$ O PT e o momento atual, série de 5 cadernos reproduzindo os debates promovidos entre 30 de abril e 28 de maio de 1983 pela Fundação Wilson Pinheiro, criada pelo PT para fins culturais e de assessoria, e publicados em julho de 1983, cujo acervo pertence à Fundação Perseu Abramo, em São Paulo. Para uma história do PT, ver Secco (2011). 
conveniências, contando com significativa participação das esquerdas e, talvez pelo fato de que os lugares que estas últimas ocuparam ainda não se encontrem devidamente identificados, saturados de memória e história das lutas sociais no Brasil das últimas décadas do século XX e princípios do atual.

\footnotetext{
${ }^{16}$ Neste contexto teve grande influência o contato mantido por exilados brasileiros com toda uma literatura crítica da ortodoxia marxista-leninista como, por exemplo, a produzida por Corneliius Castoriadis e Claude Lefort na França ou por Edward Palmer Thompson na Grã-Bretanha, bem como com a releitura da obra do italiano Antonio Gramsci e mesmo com algumas produções do chamado "eurocomunismo", movimento ocorrido em alguns partidos comunistas europeus (espanhol, francês, italiano) no sentido de incorporar referências como democracia, hegemonia e pluralismo político nas suas propostas e práticas políticas. Tudo isto, em meio a uma crescente desconfiança em face da União Soviética e dos demais regimes do "Socialismo Realmente Existente" (SOREX), como o denominou Rudolf Bahro (1982), influenciou bastante o pensamento de esquerda no Brasil no processo de desagregação da ditadura e de democratização do país, mas um tratamento mais aprofundado excede os objetivos deste artigo.
} 


\section{Referências}

\section{Arquivísticas (datilografadas, mimeografadas ou impressas na clandestinidade)}

Acervo 72, Organizações e Partidos Políticos, caixas 1 a 5, pertencente ao Arquivo Edgard Leuenroth da Universidade Estadual de Campinas (UNICAMP).

Nova Luta (órgão do Movimento pela Emancipação do Proletariado), várias edições, acervo de periódicos pertencente ao Centro de Documentação e Memória (CEDEM) da Universidade Estadual Paulista (UNESP), São Paulo.

O PT e o momento atual (5 cadernos). São Paulo: Fundação Wilson Pinheiro, 1983, acervo pertencente à Fundação Perseu Abramo, São Paulo.

Impressas:

ALMEIDA, Maria Herminia Tavares. Crise econômica e interesses organizados: 0 sindicalismo no Brasil nos anos 80. São Paulo: EDUSP,1996.

AMAZONAS, João. A socialdemocracia, instrumento do capitalismo, Revista Princípios, no. 2, São Paulo: Editora Anita Garibaldi, junho de 1981, p. 3-10.

ANTUNES, Ricardo. O novo sindicalismo no Brasil. Campinas: Pontes, 1995.

BAHRO, Rudolf. Crítica ao socialismo realmente existente. São Paulo: Brasiliense, 1982.

BENJAMIIN, Walter. Sobre o conceito de História. In: BENJAMIN, Walter. Obras escolhidas: vol. 1: magia e técnica, arte e política. São Paulo: Brasiliense, 1985.

CORDEIRO, Janaina Martins. A ditadura em tempos de milagre: comemorações, orgulho e consentimento. Rio de Janeiro: FGV, 2015.

DAL MOLIN, Naiara. Sindicato e Estado no Brasil: o sindicalismo no período populista e o Novo Sindicalismo, Pensamento Plural, Pelotas: Programa de Pós-Graduação da Universidade Federal de Pelotas, n.13, p. 89-108, julho/dezembro 2013.

FEBVRE, Lucien. Manifesto dos Anais novos (1946). In: FEBVRE, Lucien. Combates pela história. Lisboa: Presença, 1985. 
FREIRE, Alípio. Organizações e movimentos populares e de trabalhadores na segunda metade dos anos 1970 ou de um tempo quando não havia guias geniais dos povos, In: MAUÊS, Flamarion e ABRAMO, Zilah Wndel (Org.). Pela democracia, contra o arbítrio: a oposição democrática do golpe de 1964 à campanha das Diretas Já. São Paulo: Fundação Perseu Abramo, 2006.

HUMPHREY, John. Controle capitalista e luta operaria na indústria automobilística brasileira: fazendo milagre. Petrópolis: Vozes, 1982.

PARANHOS, Kátia Rodrigues. Mentes que brilham: sindicalismo e práticas culturais dos metalúrgicos de São Bernardo. 2002, Tese (Doutorado em História - Universidade de Campinas, Campinas, 2002.

PRIMO, Antônio Aparecido. O Centro Educacional Tiradentes: Escola do Sindicato dos Metalúrgicos de São Bernardo do Campo e Diadema (1974-1979). 1997, Dissertação (Mestrado em História) - Universidade de São Paulo, São Paulo, 1997.

RIDENTI, Marcelo. O fantasma da revolução brasileira. $2^{\text {a }}$. ed.). São Paulo: UNESP, 2010.

SADER, Eder. Quando novos personagens entraram em cena: experiências, falas e lutas dos trabalhadores da Grande São Paulo, 1970-1980. Rio de Janeiro: Paz e Terra, 1988.

São Paulo 1975: crescimento e pobreza. São Paulo: Loyola, 1976.

SECCO, Lincoln. História do PT . Cotia/SP: Ateliê, 2011.

VEJA, São Paulo, 14 de setembro de 1977.

WEINRICH, Harald. Lete: arte e critica do esquecimento. Rio de Janeiro: Civilização Brasileira, 2001.

YATES, Frances A. A arte da memória. Campinas: UNICAMP, 2007. 
Recebido em 15/08/2015 Aprovado em 10/10/2015

Universidade do Estado de Santa Catarina - UDESC Programa de Pós-Graduação em História - PPGH Revista Tempo e Argumento Volume 07 - Número 16 - Ano 2015 tempoeargumento@gmail.com 